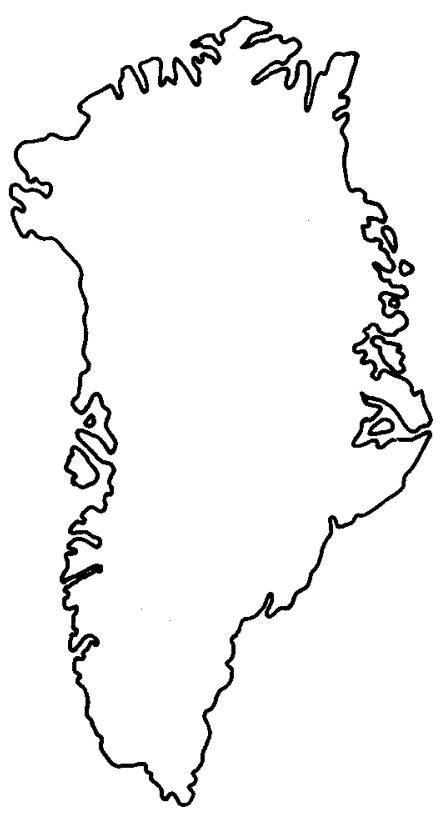

\title{
Historical fluctuations of calving glaciers in South and West Greenland
}

\begin{abstract}
Anker Weidick
Fluctuations of calf-ice producing outlets of the Julianehåb ice cap and other local glaciers in South Greenland, and outlets of the Inland Ice in South and West Greenland between latitudes $60^{\circ}$ and $73^{\circ} \mathrm{N}$ from $c$. A.D. 1850 to the present time are reviewed. Seasonal variations of the fast running tidewater glaciers (ice streams) may veil long term trends, but in general it is concluded that the mode of activity (advance or retreat) is nearly synchronous for the outlets and their neighbouring land-based segments, whereas amplitude differs; topographical control is important for short-term fluctuations but should not be over-emphasised. The situation around 1990 is one of spreading readvance and the observed behavioural patterns fit with Huybrechts' model for the present dynamic situation of the ice cover. This model indicates that the ice sheet generally is expanding as a consequence of the climatic cooling since the Holocene climatic optimum but also locates areas with present thinning of the ice margin.
\end{abstract}

A. W., Geological Survey of Greenland, Øster Voldgade 10, DK-1350 Copenhagen, Denmark.

The compilation of the fluctuations of calf-ice producing outlets of the Julianehaib ice cap and other local glaciers in South Greenland and of the Inland Ice in South and West Greenland presented here was made in connection with a workshop on the possible implication of global warming for the iceberg and sea ice regimes. The workshop, held in Copenhagen at the Danish Polar Center, 13-15 September 1993, was initiated by Ross Brown (Ice Centre Environment Canada) and arranged by $\mathrm{N}$. Reeh. The information covers 40 more or less calf-ice producing outlets of the Inland Ice proper, 14 outlets of the Julianehåb ice cap and 2 larger local glaciers (1AA11013 and 1AA12005), i.e. nearly all the calf-ice producing glaciers in the fjords of this region (Figs 1-3). The data for this compilation were collected from historical sources (old descriptions, pictures, maps), in places supplemented with lichenometrical or relative geomorphological dating.

Although the descriptions of Greenland glaciers go back to the early 1700 s, the earliest substantial information on glacial fluctuations derives from the observations and data collected by H. Rink (1857); the systematic mapping and descriptions of West Greenland after 1878, coupled with the growing international scientific interest for the Greenland ice sheet, produced comprehensive new data up to the present day.

\section{Presentation and errors in the information}

The aim of this compilation is a uniform description of changes of all glaciers in equidistant graphs, allowing direct comparison of the fluctuations of the individual outlets. Fluctuations are indicated by the position of the central parts of the glacier front, in most cases given as the distance from the maximum extent of the outlet in historical time, shown by the trimline zone. However, this does not apply for continuously expanding outlets, where the datum line usually refers to the maximum extent. The glacier may later have continued retreat or started expansion (e.g. 1GB06001 Alángordliup sermia and 1FC19001 Nordenskiöld Gletscher in Fig. 3).

The scatter of data points, especially for the oldest parts of the curves, data 'inherited' from older maps, misinterpretation of descriptions or comparison of terrestrial photographs from different angles, are all errors difficult to quantify. Subjective doubts are therefore given as broken lines in the diagrams, and should be considered here as trends, rather than exact positions of the glacier.

'Advance' of the outlets is characterised by upslope trend and 'retreat' as a downslope trend of the curves. For the majority of glaciers these trends are parallel, and the descriptions below therefore concentrate on specific response features at a few glaciers.

On the diagrams the name of the glacier (or the name 


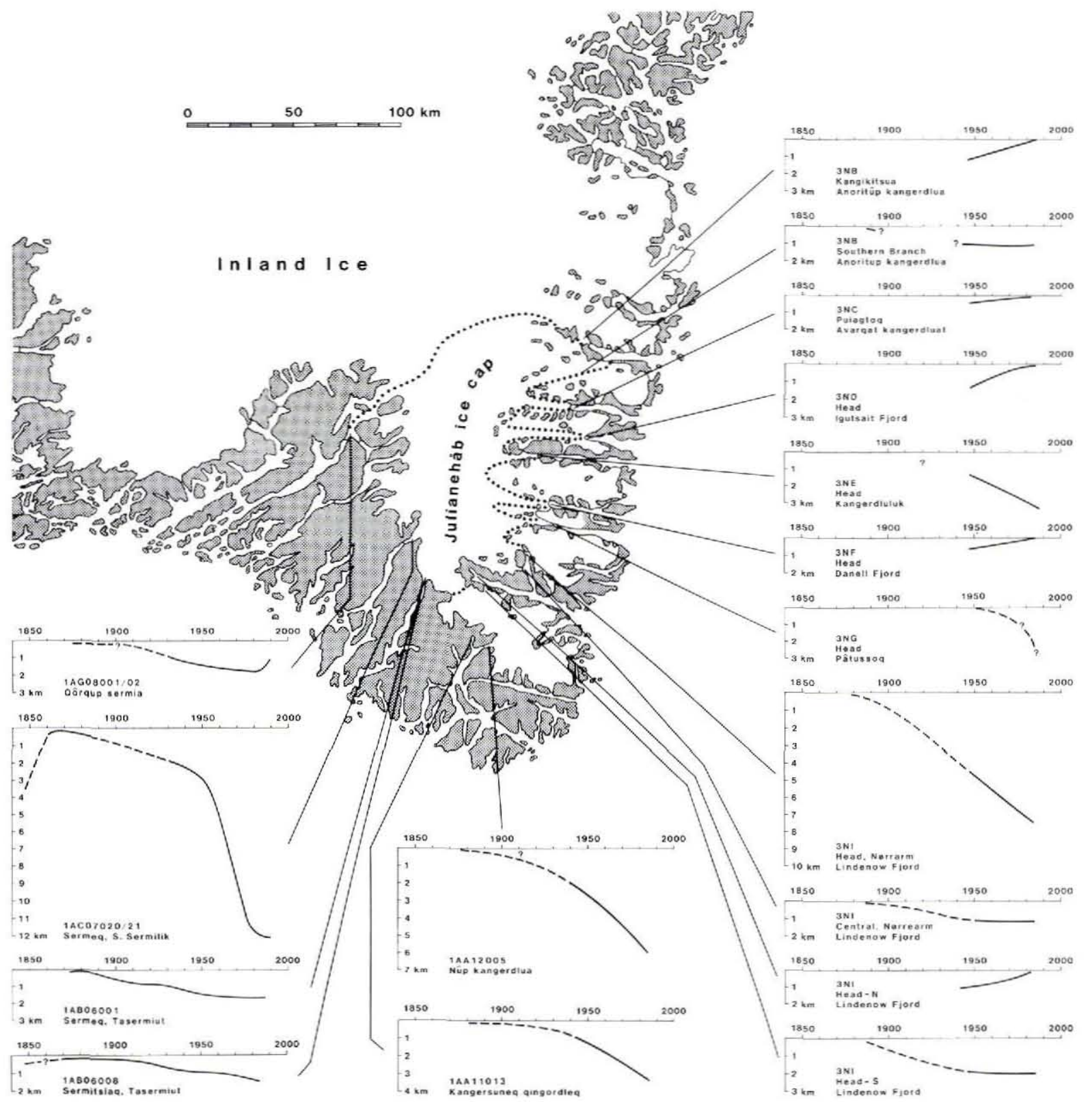

Fig. 1. Fluctuations of local calving or coastal glaciers 1850-1985, South Greenland. The southern limit of the Inland Ice against the Julianehăb ice cap is marked.

of the adjacent fjord) and its identification code (Weidick et al., 1992) is added to the fluctuation graphs in Figs $1-3$. Old Greenlandic spelling of place names is used throughout for convenience, since this is still used on most published maps of the region.

\section{South Greenland}

The pronounced alpine terrain of South Greenland is dominated by a cover of merging firn areas, in the follow- ing denoted as the Julianehăb ice cap (Fig. 1). To the north this ice cap merges with the Inland Ice proper, and the limit between the two ice covers is placed where most nunataks disappear beneath the Inland Ice.

The only outlet of this region with the character of an ice stream is 1AG08001-02 (Qôrqup sermia), which drains westwards and receives contributions from both the Julianehåb ice cap and from the Inland Ice proper.

Historical information is sparse for the south-east coast of Greenland, and for major parts only dates back to the 


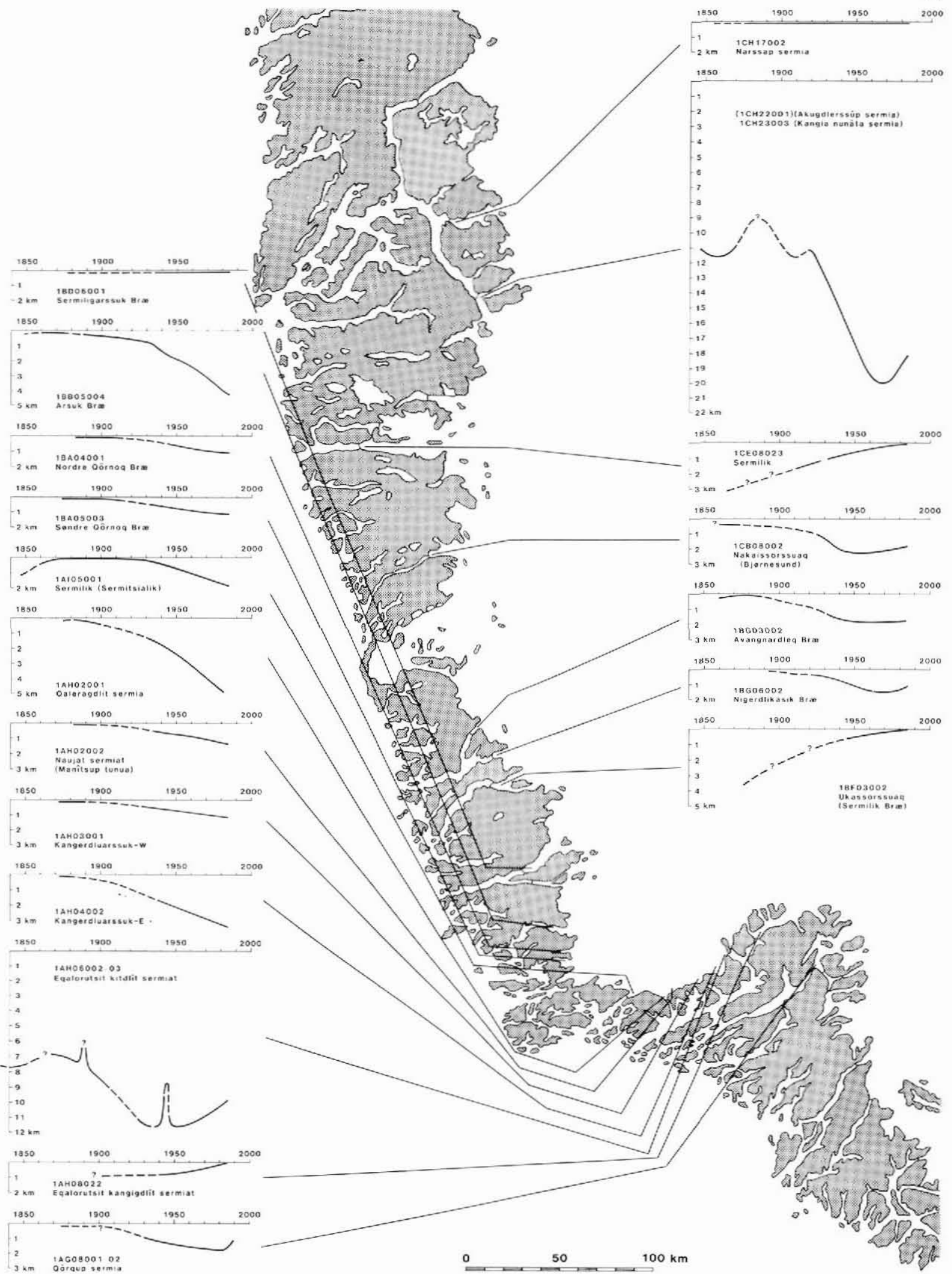

Fig. 2. Fluctuations of calving or coastal glaciers 1850-1985, southern West and South-West Greenland. 


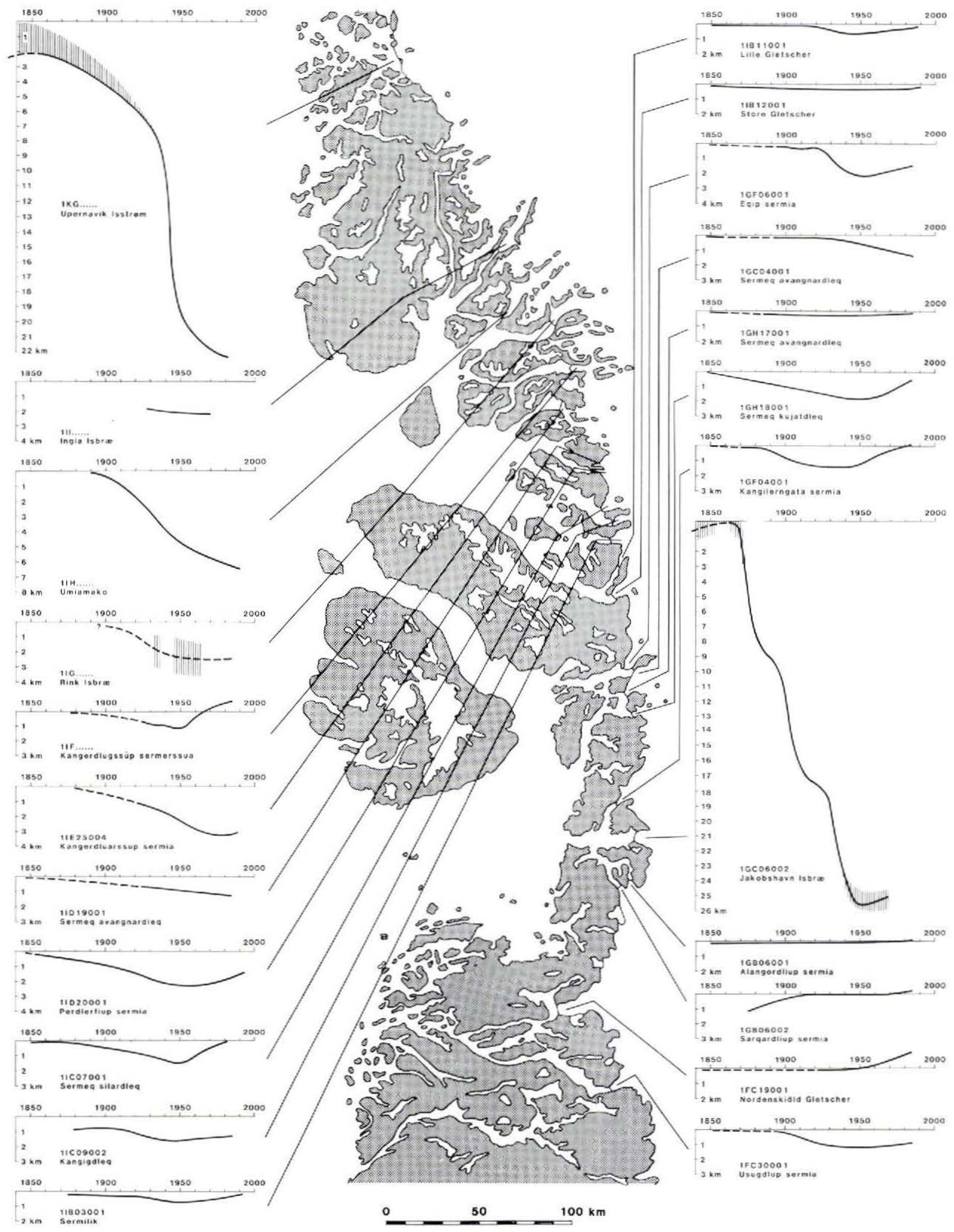

Fig. 3. Fluctuations of calving or coastal glaciers 1850-1985, central West and part of North-West Greenland. 
1930s or 1940s, whereas the western parts of the Julianehåb ice cap are covered by information at places reaching back to the early 1800 s.

Advance since the 1930s has dominated most of the north-eastern outlets (Anoritup kangerdlua to Danell Fjord) whereas recession dominates for the south-eastern outlets and all the described glaciers on the south and west coast of South Greenland (Fig. 1).

The pronounced strong recession of $3 \mathrm{NI}$ (Nørrearm), 1AA12005 (Nûp kangerdlua), 1AA11013 (Kangersuneq qingordleq) and 1AC07020-21 (Sermeq in Søndre Sermilik fjord), exhibit parallel features. They all descend into 1-2 km wide, uniform channel-shaped fjords with a very low surface angle and show little frontal calving. During the first half of this century their frontal situation showed only little recession; however the thinning of the entire outlet ended in break-up and strong frontal recession during the last half of the century. The most recent slow down in the recession of 1AC07020-21 (Sermeq in Søndre Sermilik) is due to its present termination in the head of the fjord, where the glacier lobe now descends to sea level at a very steep angle. For this glacier alone the preceding advance can be estimated to have started in the middle of the 1800s (Holm, 1883).

The same story as that of Sermeq in Søndre Sermilik is found for 1AB06001 (Sermeq in Tasermiut fjord), but with a smaller amplitude (total recession only c. $2 \mathrm{~km}$ ). The neighbouring glacier in Tasermiut (1AB06008 Sermitsiaq) had originally a partly calving front but is land based today.

\section{Southern West and South-West Greenland}

During this century the situation in southern West and South-West Greenland (Fig. 2) has been characterised by nuclei of stationary or advancing outlets from highland or upland sectors of the Inland Ice. They are located around 1AH08022 (Eqalorutsit kangigdlît sermiat), 1BF03002 (Ukâssorssuaq), 1CE08023 (Sermilik) and north of 1CH17002 (Narssap sermia).

The intervening outlets from lowland areas of the ice sheet margin were often advancing in the last part of the 19th century to a maximum for historical time, only to recede during the first half of this century. This response is almost synchronous for calving and land based outlets in these regions, but the amplitude is usually greater $(2-25 \mathrm{~km})$ for calving outlets than for those of land-based or lake-bound outlets (Weidick, 1968). During the recession in this century parts of the Inland Ice margin and outlets between $1 \mathrm{AH} 04002$ (Kangerdluarssuk-E) and 1BA04001 (Nordre Qôrnoq Bræ) in South Greenland were transformed from calving to partially or wholly land-based glaciers.
Short term pulsation has been observed at $1 \mathrm{AH} 06002$ (Eqalorutsit kitdlît sermiat), and both this glacier and $1 \mathrm{CH} 23003$ (Kangia nunâta sermia) show extreme recession initiated as early as in the 1700 s. They are both characterised by a relatively high calf-ice production (Weidick et al., 1992) and seem to act as large sinks for large parts of the ice margin. This is demonstrated by a thinning of about $300-400 \mathrm{~m}$ of the Inland Ice margin for this century as against a figure of usually under $100 \mathrm{~m}$ for lowland regions.

Other large calf-ice producing drains (e.g. 1AG08001-02 Qôrqup sermia, 1AH08022 Eqalorutsit kangigdlît sermiat and 1BF03002 Ukâssorssuaq) have shown small recession or steadily advancing behaviour since the 1800 s.

\section{Central West and North-West Greenland}

The fluctuations of the 23 more or less calf-ice producing outlets from the central West and North-West Greenland ice sheet margin (Fig. 3) generally show the same picture as the glaciers from South Greenland for lowland or upland areas: advance of most lobes to near maximum extent in the last half of the 19th century, followed by a general recession in the first half of the present century and subsequent readvance in the last half. At many localities readvances have now once again reached positions that were determined as maxima in the late 1800 s.

Seasonal variations of up to $3 \mathrm{~km}$ can veil to some degree the superimposed longer term trend. Examples of observed seasonal change are indicated by vertical hatching on Fig. 3.

Sectors with stable or expanding behaviour throughout the last century are also encountered in the central West or North-West Greenland region, especially in the sectors between 1FC19001 (Nordenskiöld Gletscher) and 1GB06001 (Alángordliup sermia). Nordenskiöld Gletscher seems to have built up a frontal tidal flat throughout the 19th century so calving parts of the front may have been reduced at present.

Glaciers with extreme variation, and showing a marked thinning during this century are: 1GC06002 (Jakobshavn Isbræ) and 1KG (Upernavik Isstrøm). Both glaciers reached their maxima in the middle of the 1800s and have retreated markedly this century. Jakobshavn Isbræ seems to be in a period of stability whereas Upernavik Isstrøm may continue recession. In this context it should be noted that Upernavik Isstrøm is at the southern part of an Inland Ice margin, which is separated from Melville Bugt by only a narrow standflat or archipelago, and which generally has exhibited strong recession throughout the 20th century (cf. Kollmeyer, 1980). 


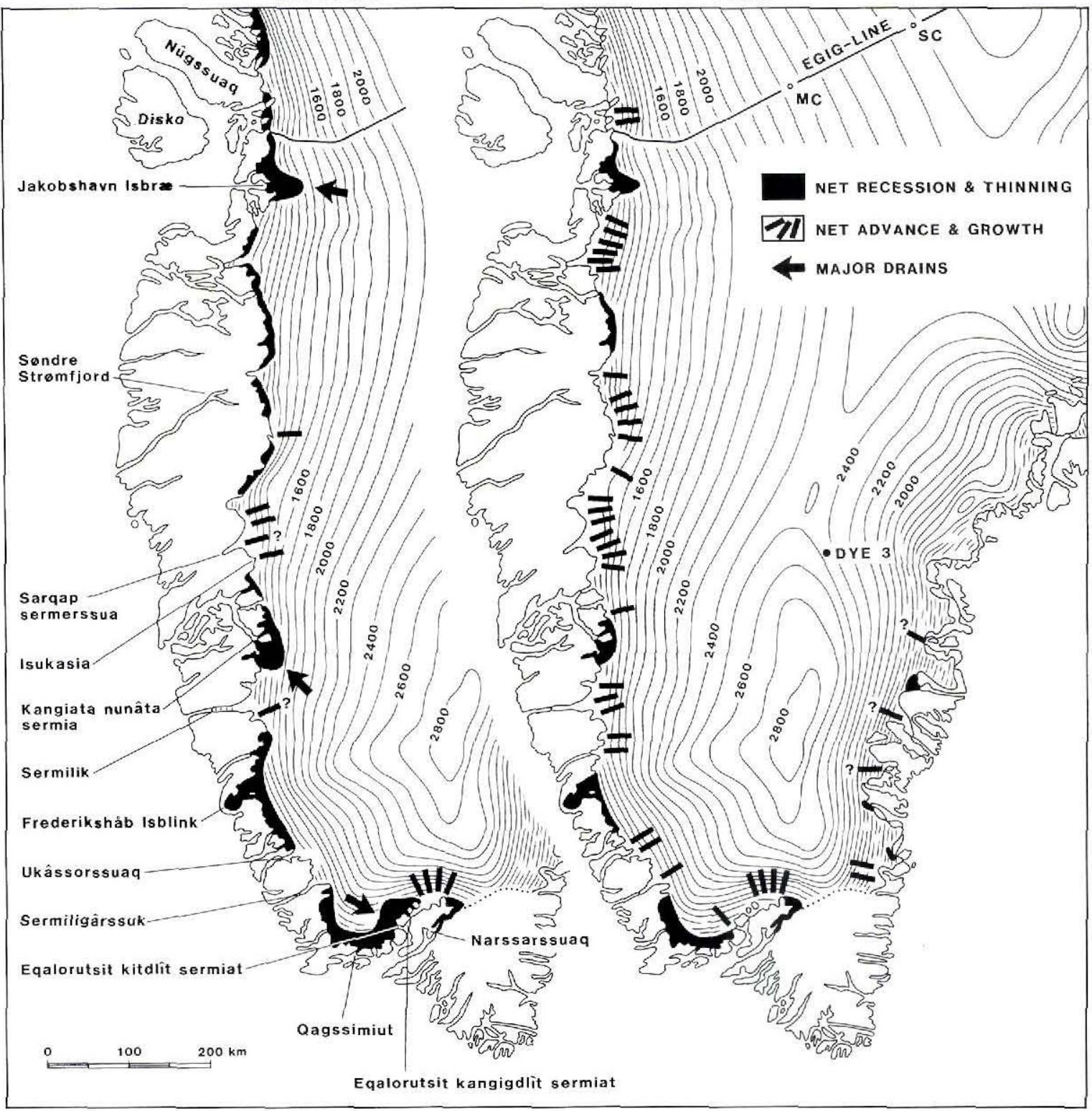

Fig. 4. Marginal activity in 1950 and 1985. Width of the black zone indicates the estimates of thinning and recession. The trend of the western part of the EGIG-line is shown with the stations of Milcent (MC) and Station Centrale (SC). The position of the Dye 3 station is also indicated. Height contour lines according to Bindschadler et al. 1989. After Weidick 1991.

\section{Conclusion}

A summary of the recent fluctuations (c. 1950-1985) of 267 sectors of the western margin of the Inland Ice between latitudes $61^{\circ}$ and $72^{\circ} \mathrm{N}$ was given by Weidick (1991). It was concluded that in this period a 'turn of the tide' took place in the sense that many of the outlets that had shown recession before $c .1950$ readvanced after this time. This readvance started and spread from highland nuclei where the outlets had either maintained a maximum position or showed a steady advance throughout the last 100-200 years (Fig. 4).

The longer trends of calving glaciers given here can be compared with older data of other outlet types (Weidick. 1968) but the result is the same, namely that there are nuclei of relatively constant growth interspersed with lowland areas where outlet fluctuations mainly follow changes in air temperature (ablation). The explanation 
given by Weidick (1991) was that the long term effects of accumulation changes interfered with the instantaneous impact of changes in air temperature.

A sophisticated model of the Inland Ice response given by Huybrechts (1993) includes isostasy, thermo-dynamical coupling and slow advection of Holocene ice in basal layers of the ice sheet. He concluded that the ice sheet has still not adjusted to past climatic fluctuations, i.e. that it is still thickening with an average growth of almost $1 \mathrm{~cm}$ ice a year. The growth is unevenly distributed, with maxima at the south-western ice margin which seems to coincide with the observed nuclei of growth shown here. Huybrechts also considers that this long-term trend temporarily and locally can be matched by changes in temperature.

The long-term general trends of calving outlets are also locally and temporarily modified by morphological control, e.g. longer stand stills at thresholds or widenings of fjords (Mercer, 1961). However, that the behaviour of West Greenland calving glaciers during recent decades has been related more to topographic than climatic factors (Warren, 1992) may be to over-emphasise local shortterm events of the glacier front. Calving glaciers might well respond in 'jumps' where neighbouring land-based glaciers show smoother behaviour through the decades but with the same trends. No sectors of the Inland Ice are isolated units (although locally they can have the specific dynamics of ice streams) but are parts of an entire ice sheet.

Locations of even major calf-ice producing outlets may change. Thus Jakobshavn Isbræ $c$. 9000 years ago ended on the iceberg bank just south of the town of Jakobshavn (Ilulissat). The maximum depth of the bank is c. $200 \mathrm{~m}$ implying that the frontal thickness of Jakobshavn Isbre at that time was scarcely a third of the present, i.e. that calf-ice production was also extremely low compared to the present day (c. $30 \mathrm{~km}^{3} \mathrm{a}^{-1}$ ). It is presumed that the major calf-ice production of the ice margin at that time was located at neighbouring ice streams in Disko Bugt, and that large-scale fluctuations (glacial/interglacial changes) therefore imply a kind of flip-flop location of major ice streams at different times of deglaciation.

In consideration of the future development of calf-ice producing outlets related to a shrinking ice sheet (as a consequence of the greenhouse effect), the strandflat (Fig. 2) between 1AH04002 (Kangerdluarssuk-E) and 1BB05004 (Arsuk Bræ) may be taken as a small-scale illustration. As a consequence of recession here increasing portions of former calving parts of the Inland Ice margin now rest on land. The model of a deglaciated Greenland (simplified version, e.g. in Letréguilly et al., 1991) indicates the deglaciated base of Greenland as a western lowland gradually sloping up to the high mountains of East Greenland. A recession implies that a decreasing part of the ice margin will terminate in fjords and this will then induce a time lag in deglaciation due to the diminished calf-ice production.

\section{References}

Holm, G. F. 1883: Geographisk Undersøgelse af Grønlands sydligste del. Meddr Grønland 6(4), 147-181.

Huybrechts, P. 1993: Modelling the present evolution of the Greenland ice sheet. In Reeh \& Oerter, H. (ed.) Mass balance and related topics of the Greenland ice sheet. Open File Ser. Gronlands geol. Unders. 93/5, 13-16.

Letréguilly, A., Huybrechts, P. \& Reeh, N. 1991: Steady-state characteristics of the Greenland ice sheet under different climates. J. Glaciol. 37(125), 149-157.

Kollmeyer, R. C. 1980: West Greenland outlet glaciers: an inventory of the major iceberg producers. Publs Ass. int. Hydrol. Scient. 126, 57-65.

Mercer, J. 1961: The response of fjord glaciers to changes in the firn limit. J. Glaciol. 3(29), 850-858.

Rink, H. 1857: Grønland, geographisk og statistisk beskrevet. Bd. 1, Nordre Inspectorat, 420 pp. Bd. 2, Sфndre Inspectorat, 588 pp. København: A. Høst og Søn.

Warren, C. R. 1992: Iceberg calving and the glacioclimatic record. Progress in Physical Geography 16(3), 253-282.

Weidick, A. 1968: Observations on some Holocene glacier fluctuations in West Greenland. Bull. Grønlands geol. Unders. 73 (also Meddr Grønland 165,6), 202 pp.

Weidick, A. 1991: Present-day expansion of the southern part of the Inland Ice. Rapp. Grønlands geol. Unders. 152, 73-79.

Weidick, A., Bøggild, C. E. \& Knudsen, N. T. 1992: Glacier inventory and atlas of West Greenland. Rapp. Gronlands geol. Unders. 158, $194 \mathrm{pp}$. 